\section{EKSEKUSI YANG TIDAK DAPAT DIJALANKAN MENURUT HUKUM ACARA PERDATA ${ }^{1}$ Oleh: Rahmawati Kasim²}

\begin{abstract}
ABSTRAK
Tujuan dilakukannya penelitian ini adalah untuk mengetahui bagaimana cara pelaksanaan eksekusi menurut Hukum Acara Perdata dan bagaimana jika eksekusi tidak dapat dijalankan apabila putusan pengadilan sudah mempunyai kekuatan hukum tetap (in kracht van gewijsde). Dengan menggunakan metode penelitian yuridis normative, dapat disimpulkan: 1 . Cara pelaksanaan eksekusi dalam Hukum Acara Perdata adalah: Pelaksanaan putusan atas perintah dan atau dipimpin ketua pengadilan Negeri, sebelum pelaksanaan eksekusi diberikan peringatan (aanmaning). Jika tidak mengindahkan, maka dilakukan sita eksekusi. Penyitaan dilakukan oleh panitera atas perintah Ketua Pengadilan Negeri. Sita eksekusi harus disaksikan oleh dua orang saksi. Barang yang disita tetap berada pada yang disita atau ditempatkan pada penyimpanan yang layak. Penyitaan benda tidak bergerak dilakukan dengan membuat berita acara. 2. Putusan Hakim yang sudah mempunyai kekuatan hukum tetap tidak dapat dieksekusi, alasannya: Karena harta kekayaan tereksekusi tidak ada. Karena putusan bersifat deklaratoir (pernyataan). Barang yang menjadi objek eksekusi berada ditangan pihak ketiga. Eksekusi tidak dapat dijalankan terhadap penyewa. Karena tanah yang akan dieksekusi tidak jelas batas-batasnya. Tanah berubah status menjadi tanah Negara. Barang yang menjadi objek eksekusi berada di luar Negeri. Terdapat dua putusan yang saling bertentangan.

Kata kunci: Eksekusi, tidak dapat dijalankan, hukum acara, perdata
\end{abstract}

\section{PENDAHULUAN}

\section{A. Latar Belakang}

Putusan pengadilan merupakan sesuatu yang sangat diinginkan atau dinanti-nantikan oleh pihak-pihak yang berperkara untuk menyelesaikan sengketa mereka dengan

\footnotetext{
${ }^{1}$ Artikel Skripsi. Dosen Pembimbing : Berlian Manoppo, $\mathrm{SH}, \mathrm{MH}$; Dr. Elisabeth E. Winokan, SH, M.Si

2 Mahasiswa pada Fakultas Hukum Unsrat, NIM. 13071101697
}

sebaik-baiknya. Sebab dengan putusan pengadilan tersebut pihak-pihak yang bersengketa mengharapkan adanya kepastian hukum dan keadilan dalam perkara yang mereka hadapi. ${ }^{3}$

Untuk dapat memberikan putusan pengadilan yang benar-benar menciptakan kepastian hukum dan mencerminkan keadilan, hakim sebagai aparatur negara dan sebagai wakil Tuhan yang melaksanakan peradilan harus benar-benar mengetahui duduk perkara yang sebenarnya dan peraturan hukum yang akan diterapkan baik peraturan hukum yang tertulis dalam perundang-undangan maupun peraturan hukum yang tidak tertulis atau hukum adat. ${ }^{4}$

Putusan pengadilan adalah pernyataan hakim yang diucapkan pada sidang pengadilan yang terbuka untuk umum untuk menyelesaikan atau mengakhiri perkara perdata. ${ }^{5}$ Setiap putusan pengadilan tertuang dalam bentuk tertulis yang harus ditandatangani oleh hakim ketua sidang dan hakim-hakim anggota yang ikut serta memeriksa dan memutuskan perkara serta panitera pengganti yang ikut bersidang ${ }^{6}$ (Pasal 23 (2) UU No. 4/2004). Untuk mencegah adanya perbedaan antara bunyi putusan yang diucapkan di persidangan dengan yang tertulis, Mahkamah Agung dengan Surat Edaran No. 5/1959 tanggal 20 April 1959 dan No. 1/1962 tanggal 7 Maret 1962 telah menginstruksikan kepada para hakim agar pada waktu putusan pengadilan tersebut diucapkan konsepnya harus sudah disiapkan. ${ }^{7}$ Karena jabatannya, ketika bermusyawarah hakim wajib mencukupkan semua alasan-alasan hukum yang tidak dikemukakan oleh kedua belah pihak. Hakim wajib mengadili semua bagian gugatan. Hakim dilarang menjatuhkan putusan atas hal-hal yang tidak diminta atau

\footnotetext{
3 Moh. Taufik Makarao, Pokok-Pokok Hukum Acara Perdata, Rineka Cipta, Jakarta, 2009, hal. 124

${ }^{4}$ Ibid, hal. 124

${ }^{5}$ Riduan Syahrani, Hukum Acara Perdata di Lingkungan Peradilan Umum, Pustaka Kartini, Jakarta, 1988, hal. 83

${ }^{6}$ Lihat Penjelasan Pasal 23 ayat 2, UU No. 4 Tahun 2004, tentang Kekuasaan Kehakiman

${ }^{7}$ Lihat Surat Edaran Mahkamah Agung RI No. 5 Tahun 1959
} 
mengabulkan lebih daripada yang digugat ${ }^{8}$ Pasal 178 (1 s.d. 3) HIR/ 189 (1 s.d. 3) RBG).

Eksekusi adalah hal menjalankan putusan Pengadilan yang sudah berkekuatan hukum tetap Putusan Pengadilan yang dieksekusi adalah putusan Pengadilan yang mengandung perintah kepada salah satu pihak untuk membayar sejumlah uang, atau juga pelaksanaan putusan hakim yang memerintahkan pengosongan benda tetap, sedangkan pihak yang kalah tidak mau melaksanakan putusan itu secara sukarela sehingga memerlukan upaya paksa dari Pengadilan untuk melaksanakannya. ${ }^{9}$

Putusan Pengadilan yang dapat dilaksanakan adalah putusan yang mempunyai kekuatan eksekutorial. Ada pun yang memberikan kekuatan eksekutorial pada putusan Pengadilan terletak pada kepada putusan yang berbunyi "Demi Keadilan Berdasarkan Ketuhanan Yang Maha Esa". Di samping itu putusan Pengadilan yang mempunyai titel eksekutorial adalah putusan yang bersifat atau yang mengandung amar "condemnatoir". ${ }^{10}$ Sedangkan putusan Pengadilan yang bersifat deklaratoir dan constitutif tidak dilaksanakan eksekusi karena tidak memerlukan eksekusi dalam menjalankannya. Eksekusi pada hakekatnya tidak lain ialah realisasi daripada kewajiban pihak yang kalah untuk memenuhi prestasi yang tercantum dalam putusan Pengadilan tersebut. Pihak yang menang dapat memohon eksekusi pada Pengadilan yang memutus perkara tersebut untuk melaksanakan putusan tersebut secara paksa (execution force).

\section{B. Rumusan Masalah}

1. Bagaimana cara pelaksanaan eksekusi menurut Hukum Acara Perdata?

2. Bagaimana jika eksekusi tidak dapat dijalankan apabila putusan pengadilan sudah mempunyai kekuatan hukum tetap (in kracht van gewijsde)?

\section{Metode Penelitian}

\footnotetext{
${ }^{8}$ Lihat Penjelasan Pasal 178 ayat 1-3 HIR dan Pasal 189 ayat $1-3 \mathrm{RBg}$

9 H. Abdul Manan, Penerapan Hukum Acara Perdata di Lingkungan Peradilan Agama, Kencana, Jakarta, 2006, hal. 313

${ }^{10}$ Ibid, hal. 313
}

Dalam penulisan skripsi ini menggunakan penelitian hukum normatif, menurut Soerjono Soekanto dan Sri Mamudji, pada penelitian hukum normatif, bahan pustaka merupakan bahan dasar yang disebut data sekunder. ${ }^{11}$ Penelitian hukum normatif yang oleh Soetandyo Wignjosoebroto disebut sebagai "penelitian doktrinal."

\section{PEMBAHASAN}

\section{A. Cara Pelaksanaan Eksekusi Menurut Hukum Acara Perdata}

Dalam menjalankan eksekusi terhadap perkara-perkara perdata yang menjadi wewenang Pengadilan dapat ditempuh tahapan-tahapan sebagai berikut: ${ }^{13}$

a. Permohonan pihak yang menang

Jika pihak yang kalah tidak bersedia melaksanakan putusan Pengadilan secara sukarela, maka pihak yang menang dapat mengajukan permohonan kepada Ketua Pengadilan yang memutuskan perkara tersebut untuk dijalankan secara paksa halhal yang telah disebutkan dalam amar putusan. Permohonan pengajuan eksekusi kepala Ketua Pengadilan merupakan suatu keharusan yang harus dilakukan oleh pihak yang menang agar putusan tersebut dapat dijalankan secara paksa ${ }^{14}$ sebagaimana tersebut dalam Pasal 207 ayat (1) R.Bg dan Pasal 196 HIR. Jika para pihak yang menang ingin putusan Pengadilan supaya dijalankan secara paksa, maka ia harus membuat surat permohonan yang diajukan kepada Ketua Pengadilan yang memutus perkara, memohon agar putusan supaya dijalankan secara paksa karena pihak yang kalah tidak mau melaksanakan isi putusan tersebut. Tanpa ada surat permohonan tersebut maka eksekusi tidak dapat dilaksanakan.

b. Penaksiran biaya eksekusi

Jika Ketua Pengadilan telah menerima permohonan eksekusi dari pihak yang berkepentingan, maka segera

\footnotetext{
${ }^{11}$ Soerjono Soekanto dan Sri Mamudji, Penelitian Hukum Normatif, Suatu Tinjauan Singkat, RajaGrafindo Persada, Jakarta, 2004, hal. 24

12 Bambang Sungono, Metodologi Penelitian Hukum, RajaGRafindo Persada, Jakarta, 2001, hal. 43

${ }^{13}$ H. Abdul Manan, Loc Cit, hal. 316

${ }^{14}$ Lihat Penjelasan Pasal 207 ayat (1) RBg dan Pasal 196 HIR
} 
memerintahkan meja satu untuk menaksir biaya eksekusi yang diperlukan dalam pelaksanaan eksekusi yang dilaksanakannya.

Biaya yang diperlukan meliputi biaya pendaftaran eksekusi, biaya saksi-saksi, dan biaya pengamanan serta lain-lain yang dianggap perlu. Setelah biaya eksekusi tersebut dibayar oleh pihak yang menghendaki eksekusi kepada Panitera atau petugas yang ditunjuk untuk mengurus biaya perkara, barulah permohonan eksekusi tersebut didaftarkan dalam register eksekusi.

c. Melaksanakan peringatan (Aan maning) Aan maning merupakan tindakan dan upaya yang dilakukan oleh Ketua Pengadilan berupa teguran kepada pihak yang kalah agar ia melaksanakan isi putusan secara sukarela. Aan maning dilakukan dengan melakukan panggilan terhadap pihak yang kalah dengan menentukan hari, tanggal, dan jam persidangan dalam surat panggilan tersebut.

Memberikan peringatan (Aan maning) dengan cara: ${ }^{15}(1)$ melakukan sidang insidental yang dihadiri oleh Ketua Pengadilan, Panitera dan pihak yang kalah, (2) memberikan peringatan atau teguran supaya ia menjalankan putusan hakim dalam waktu delapan hari, (3) membuat berita acara Aan maning dengan mencatat semua peristiwa yang terjadi di dalam sidang tersebut sebagai bukti autentik, bahwa Aan maning telah dilakukan dan berita acara ini merupakan landasan bagi perintah eksekusi yang akan dilaksanakan selanjutnya. Apabila pihak yang kalah tidak hadir dalam sidang Aan maning, dan ketidakhadirannya dapat dipertanggungjawabkan, maka ketidakhadirannya itu dapat dibenarkan dan pihak yang kalah itu harus dipanggil kembali untuk Aan maning yang kedua kalinya. Jika ketidakhadiran pihak yang kalah setelah dipanggil secara resmi dan patut tidak dapat dipertanggungjawabkan, maka gugur haknya untuk dipanggil lagi,

\footnotetext{
${ }^{15}$ Kadir Muhammad Abdul, Hukum Acara Di Indonesia, Alumni, Bandung, 1978, hal. 52
}

tidak perlu lagi proses sidang peringatan dan tidak ada tenggang masa peringatan. Secara ex officio Ketua Pengadilan dapat langsung mengeluarkan surat penetapan perintah eksekusi kepada Panitera/Juru Sita. ${ }^{16}$

d. Mengeluarkan surat perintah eksekusi Apabila waktu yang telah ditentukan dalam peringatan (Aan maning) sudah lewat dan ternyata pihak yang kalah tidak menjalankan putusan, dan tidak mau menghadiri panggilan sidang peringatan tanpa alasan yang sah, maka Ketua Pengadilan mengeluarkan perintah eksekusi dengan ketentuan: ${ }^{17}$ (1) perintah eksekusi itu berupa penetapan, (2) perintah ditujukan kepada Panitera atau Juru Sita yang namanya harus disebut dengan jelas, (3) harus menyebut dengan jelas nomor perkara yang hendak dieksekusi dan objek barang yang hendak dieksekusi, (4) perintah eksekusi dilakukan di tempat letak barang dan tidak boleh di belakang meja, (5) isi perintah eksekusi supaya dilaksanakan sesuai dengan amar putusan.

\section{B. Eksekusi Yang Tidak Dapat Dijalankan Walaupun Sudah Mempunyai Kekuatan Hukum Tetap (in kracht van gewijsde)}

Dalam hal menetapkan penetapan eksekusi, Ketua Pengadilan tidak mengetahui bahwa sebagian amar putusan yang akan dieksekusi tidak dapat dilaksanakan atau dijalankan. Peristiwa tersebut baru diketahui ketika Ketua Pengadilan mendapatkan laporan berita acara yang memuat keterangan terkait proses pelaksanaan eksekusi yang dibuat oleh panitera dan jurusita yang bertugas di lapangan.

Penulis berpendapat bahwa seringkali dalam melaksanakan eksekusi, Panitera atau Juru Sita hanya melaksanakan eksekusi tanpa datang langsung ke lapangan sehingga terjadi hambatan-hambatan yang ditemui di lapangan atau tempat pelaksanaan eksekusi.

Banyak hambatan yang ditemui dalam pelaksanaan eksekusi oleh Panitera atau Juru Sita di lapangan, sehingga eksekusi tidak dapat dijalankan sebagaimana mestinya. Di antara hambatan yang sering ditemukan di lapangan
${ }^{16}$ Ibid
17 Ibid 
adalah sebagai berikut: ${ }^{18}$

(1) Harta kekayaan tereksekusi tidak ada

Secara mutlak barang yang dieksekusi tidak ada, mungkin sudah habis terjual sebelum eksekusi dijalankan, atau telah musnah karena adanya bencana alam.

Tidak ditemuinya harta yang akan dieksekusi bisa juga terjadi karena tidak jelas letak barang-barang yang akan dieksekusi tidak jelas batas-batasnya, ukurannya dan mungkin juga karena adanya perubahan alamat, pada waktu 11 gugatan diajukan terletak di jalan Fatmawati No. 10 Rt. 12/ 04 ternyata setelah perkara diputus ada perubahan, terletak di jalan Argamulya No. 21 Rt. 14/02 sehingga pada waktu eksekusi dilaksanakan, letak barang tersebut sudah tidak sesuai lagi dengan apa yang tersebut dalam amar putusan.

Selain dari hal tersebut di atas, maka praktisi hukum masih mempersoalkan kepada siapa perintah eksekusi diberikan, apakah kepada Panitera atau Juru Sita, atau juga kepada kedua-duanya secara bersamaan. ${ }^{19}$ Terhadap hal ini sebenarnya dapat dipedomani beberapa ketentuan perundang-undangan. Menurut Pasal 33 ayat (3) Undang-undang Nomor 4 Tahun 2004 dikemukakan bahwa pelaksanaan putusan pengadilan dalam perkara perdata dilakukan oleh Panitera dan Juru Sita yang dipimpin oleh Ketua Pengadilan. ${ }^{20}$ Kemudian dalam Pasal 57 Undang-undang Nomor 13 Tahun 1965 ditentukan dalam perkara perdata, Panitera melaksanakan keputusan pengadilan bertindak pula sebagai Juru Sita. ${ }^{21}$ Dalam Pasal 197 ayat (2) dan ayat (6) HIR, Pasal 209 ayat (1), Pasal 210 ayat (1) R.Bg. penyitaan dilakukan oleh Panitera dengan dibantu oleh dua orang saksi. Kemudian dalam Pasal 197 ayat (3) HIR dan Pasal 209 ayat (2) R.Bg, ditentukan apabila Panitera berhalangan, ia dapat diganti oleh orang ditunjuk untuk itu.

Melihat kepada peraturan perundang-

\footnotetext{
${ }^{18}$ Elise T. Sulistini dan Rudy T. Erwin, Petunjuk Praktis Menyelesaikan Perkara-Perkara Perdata, Bina Aksara, Jakarta, 1987, hal. 62

${ }_{19}$ Ibid

${ }^{20}$ Lihat Penjelasan Pasal 33 ayat (3) Undang-Undang No. 4 Tahun 2004 tentang Kekuasaan Kehakiman

${ }^{21}$ Pengadilan sebagai juru sita, pasal 197 ayat (2), ayat (6), Pasal 209 ayat (1), Pasal 210 ayat (1) R.Bg
}

undangan tersebut, maka dapat disimpulkan bahwa yang diberi wewenang untuk melaksanakan eksekusi adalah Panitera. Apabila Panitera berhalangan maka dapat dilakukan oleh Juru Sita. Jadi tidak dilaksanakan bersama-sama, melainkan Panitera sendiri atau Juru Sita sendiri dengan dibantu oleh dua orang saksi.

- Pelaksanan eksekusi riil.

Perintah eksekusi yang dibuat Ketua Pengadilan, Panitera atau apabila ia berhalangan dapat diwakilkan kepada Juru Sita dengan ketentuan harus menyebut dengan jelas nama petugas dan jabatannya yang bertugas melaksanakan eksekusi sebagaimana diatur dalam Pasal 197 ayat (1) HIR dan Pasal 209 R.Bg. ${ }^{22}$ Dalam pelaksanaan eksekusi tersebut, Panitera atau Juru Sita dibantu dua orang saksi berumur 21 tahun, jujur dan dapat dipercaya yang berfungsi membantu Panitera atau Juru Sita yang melaksanakan eksekusi, sebagaimana diatur dalam Pasal 197 ayat (6) HIR dan Pasal 210 R.Bg.

Panitera atau Juru Sita yang melaksanakan eksekusi harus datang ke tempat objek barang yang dieksekusi, tidak dibenarkan mengeksekusi barang-barang hanya di belakang meja atau dengan cara jarak jauh. Eksekusi harus dilaksanakan sesuai dengan bunyi amar putusan, apabila barang-barang yang dieksekusi secara nyata berbeda dengan amar putusan, maka Panitera atau Juru Sita yang melakukan eksekusi harus menghentikan eksekusi tersebut, dan membuat berita acara bahwa eksekusi tidak dapat dilaksanakan karena amar putusan dengan objek yang akan dieksekusi tidak sesuai dengan kenyataan di lapangan.

Berita acara eksekusi harus memuat halhal: ${ }^{23}$ (1) jenis barang-barang yang dieksekusi, (2) letak, ukuran, dan luas barang tetap yang dieksekusi, (3) hadir tidaknya pihak yang tereksekusi, (4) penegasan.

Apabila secara nyata barang-barang'yang akan dieksekusi tidak dapat ditunjukkan oleh pemohon eksekusi maka dengan sendirinya eksekusi tidak dapat dijalankan. Sedangkan karena perubahan alamat Sebagaimana tersebut di atas, maka untuk dapat

\footnotetext{
22 Perintah Eksekusi oleh Ketua Pengadilan Kepada Panitera vide Pasal 197 ayat (1) HIR

${ }^{23}$ Elise T. Sulistini, dkk, Op Cit, hal. 62
} 
dilaksanakan eksekusi, pemohon eksekusi harus mengajukan perkara baru, dengan nomor perkara baru dan dengan petitum perbaikan amar putusan. ${ }^{24}$ Jika tanah yang akan dieksekusi tidak jelas batasnya atau belum jelas ukurannya, eksekusi dengan sendirinya juga tidak dapat dilaksanakan. Pernyataan noneksekutabel ini bersifat temporer sampai batas dan ukurannya dapat diketahui dengan jelas. Mengatasi hal ini sebaiknya diadakan pengecekan atau pemeriksaan setempat terlebih dahulu dengan dihadiri oleh pihakpihak yang berperkara. Jika berhasil ditemukan maka eksekusi dapat dijalankan, jika ternyata tidak diketemukan sama sekali, maka eksekusi tidak dapat dijalankan.

(2) Putusan bersifat deklaratoir

Sebagaimana yang telah dikemukakan di atas, bahwa putusan yang bersifat condemnatior yaitu putusan yang amarnya mempunyai sifat menghukum atau memerintahkan kepada pihak yang kalah untuk berbuat sesuatu, tidak berbuat sesuatu, membayar, membagi, membongkar dan mengosongkan benda tetap. Jika putusan tersebut tidak dilaksanakan secara sukarela oleh pihak yang kalah, maka pihak yang menang dapat minta Pengadilan yang memutuskan perkara tersebut untuk menjalankan putusan tersebut secara paksa.

Jika hakim lalai atau lupa mencantumkan amar yang bersifat condemnatoir sebagaimana tersebut di atas, maka pihak yang ingin agar putusan itu dijalankan harus mengajukan gugatan baru kepada Pengadilan yang memutuskan perkara semula, dengan dalil gugat berdasarkan putusan deklaratoir dan minta dalam petitum agar barang-barang yang telah diputus dalam perkara terdahulu supaya dieksekusi dan kalau perlu dapat diminta putusan Uitvoerbaar bij voorraad (putusan yang dapat dilaksanakan terlebih dahulu) meskipun ada banding dan kasasi. ${ }^{25}$

Yang dimaksud dengan perkara baru adalah putusan yang berdiri sendiri dengan nomor perkara lain dengan perkara yang terdahulu, Penggugat juga harus membayar biaya perkara

\footnotetext{
${ }^{24}$ Ibid, hal. 62

25 Darwan Spinst, Strategi Menyusun dan Menangani Gugatan Perdata, Citra Aditya Bakti, Bandung, 1992, hal. 14
}

secara tersendiri posita dalam perkara baru tersebut dikaitkan dengan perkara yang terdahulu dengan petitum mohon agar putusan yang terdahulu supaya dapat dijalankan dan dapat dieksekusi sebagaimana mestinya.

Ada sementara para praktisi hukum yang berpendapat bahwa pemberian jalan keluar terhadap putusan deklaratoir dan tidak mencantumkan amar yang bersifat comdemnatoir tidak dilaksanakan dengan gugat baru dengan petitum perubahan amar dan mohon dapat dieksekusi merupakan jalan keluar yang kurang tepat, sebab sangat merugikan, Penggugat dan juga akan terjadi Nebis in idem. ${ }^{26}$

Dalam praktik Peradilan hal ini sudah sangat sering dilaksanakan meskipun secara realita memang pihak Penggugat sangat dirugikan. Jika putusan yang bersifat deklaratoir itu dibiarkan, maka akan illusoir (hampa) dan tidak ada manfaat serta tidak ada kepastian hukum. Daripada putusan demikian hampa, maka sudah selayaknyalah Penggugat dianjurkan untuk mengajukan gugat lagi dengan petitum perubahan amar agar putusan yang terdahulu dapat dijalankan atau dieksekusi, meskipun mungkin dengan sedikit menanggung kerugian. Oleh karena itu kepada para hakim diharapkan agar berhati-hati dalam membuat amar putusan ini sehingga putusan yang dijatuhkan itu terhindar dari kehampaan (illusoir). ${ }^{27}$

Dalam hal gugat baru dengan petitum perubahan amar putusan, tidak akan terjadi Nebis in idem karena hakim tidak memeriksa pokok perkara yang telah diputus dalam putusan sebelumnya. Lagipula ada para pakar hukum yang berpendapat bahwa dalam hukum perdata tidak dikenal Nebis in idem, yang ada hanya dalam bidang hukum pidana.

(3) Objek eksekusi di tangan pihak ketiga

Eksekusi tidak dapat dijalankan terhadap barang yang ada ditangan pihak ketiga apabila penguasaan barang tersebut dilaksanakan berdasarkan atas alas hak yang sah. Eksekusi dapat dijalankan apabila penguasaan barang oleh pihak ketiga itu secara tidak sah atau tanpa alas hak. ${ }^{28}$ Terhadap hal ini apabila amar

\footnotetext{
${ }^{26}$ Ibid, hal. 14

27 Ibid, hal. 15

${ }^{28}$ Ibid, hal. 15
} 
putusan menegaskan bahwa objek perkara yang akan dieksekusi dapat saja dilaksanakan meskipun barang berada di tangan siapa pun. Maka eksekusi dapat dijalankan meskipun barang berada di tangan pihak ketiga.

Jika barang yang dieksekusi sedang disewa oleh pihak ketiga maka pelaksanaan eksekusi harus dihentikan, sebab perjanjian sewa menyewa terus berlanjut meskipun pemilik barang itu diganti. Eksekusi pengosongan atau penyerahan terhadap diri penyewa tidak dapat dijalankan.

Demikian juga dalam hal barang yang akan dieksekusi sedang diagunkan. Eksekusi tidak dapat dilaksanakan selama barang yang menjadi objek eksekusi itu sedang diagunkan. Selama barang tersebut diagunkan, maka barang objek eksekusi terikat kepada pemegang agunan. Eksekusi baru dapat dilaksanakan kalau barang objek eksekusi itu sudah tidak lagi menjadi objek agunan Tergugat. $^{29}$ Barang objek eksekusi yang diagunkan itu biasanya pada Bank, Perkumpulan koperasi atau pada pihak ketiga secara perorangan.

(4) Status tanah milik negara.

Jika status tanah yang disengketakan pada mulanya milik pribadi, kemudian karena sesuatu hal berubah jadi milik negara dan perubahan itu statusnya jelas, maka terhadap objek tersebut tidak dapat dijalankan eksekusinya. Sekiranya perubahan status tanah tidak jelas, maka eksekusi dapat dijalankan selama tidak ada perlawanan dari pihak penguasa. Jika ada perlawanan dari pihak penguasa, maka eksekusi harus dihentikan.

(5) Objek eksekusi berada di luar negeri.

Jangkauan hukum Indonesia hanya berlaku dalam wilayah Indonesia saja, hal ini karena hukum Indonesia menganut asas nasionalitas. Sehubungan dengan hal ini daya kekuatan putusan Pengadilan hanya meliputi wawasan Nasional Indonesia, tidak menjangkau di luar wilayah Indonesia. Oleh karena itu, eksekusi tidak dapat dijalankan jika letak objek eksekusi berada di luar Indonesia. Jika objek eksekusi berada di luar wilayah Indonesia, dan pihak yang menang bermaksud untuk memohon eksekusi kepada Pengadilan maka Pengadilan

\footnotetext{
${ }^{29}$ A. Mukti Arto, Loc Cit, hal. 19
}

harus menolaknya. ${ }^{30}$

(6) Dua putusan yang saling bertentangan.

Secara teoretis mungkin tidak masuk akal apabila ada putusan pengadilan yang bunyinya saling bertentangan satu sama lain, padahal pokok permasalahannya adalah sama. Dalam praktik sering ditemukan dua putusan yang saling bertentangan padahal pokok permasalahannya adalah sama.

Suatu putusan dapat dijalankan lebih dahulu mungkin saja menjadi bertentangan dengan putusan dalam tingkat banding atau putusan kasasi. Jika putusan tersebut sudah terlanjur dieksekusi, maka untuk memenuhi putusan banding atau kasasi menjadi batal dan harus diikuti dengan tindakan pemulihan, berupa penggantian kerugian atau penyerahan uang atau juga barang jaminan lainnya.

Selain dari hal tersebut di atas, yang dimaksud dengan putusan yang saling bertentangan adalah pertentangan antara dua putusan yang sudah mempunyai kekuatan hukum tetap, baik putusan dalam tingkat peradilan yang sama ataupun dapat terjadi dalam tingkat yang berlainan. Umpamanya ada dua putusan mengenai keahliwarisan dan pembagian harta warisan dengan objek gugatan yang sama, tetapi masing-masing Penggugat maupun Tergugat berbeda. Keadaan seperti ini mustahil bisa terjadi, akan tetapi karena pewaris sudah lama sekali meninggal dan mempunyai keturunan banyak dan bercerai-berai tempat tinggalnya, hal yang semula dianggap mustahil tersebut bisa menjadi kenyataan. ${ }^{31}$

Jadi apabila ada dua putusan yang samasama telah berkekuatan hukum tetap, tapi isinya saling bertentangan dan objek persengketaannya sama, maka secara permanen tidak dapat dieksekusi sampai pertentangan itu dihilangkan. Cara menghilangkan saling pertentangan tersebut dapat dilaksanakan melalui gugatan apabila pihaknya tidak sama atau melalui peninjauan kembali apabila pihaknya sama.

Karena itu, jika pihak yang menang dalam suatu perkara yang telah diputus oleh pengadilan dan putusan itu telah mempunyai kekuatan hukum tetap, lalu dimohonkan

\footnotetext{
${ }^{30}$ Djazuli Bachir, Loc Cit, hal. 14

${ }^{31} \mathrm{Ibid}$, hal. 125
} 
eksekusi kepada pengadilan yang memutuskan perkara tersebut, maka pengadilan yang memutus perkara itu harus segera melaksanakannya. Yang dapat mengesampingkan eksekusi hanya perdamaian antara pihak yang berperkara.

(7) Penundaan Eksekusi Yang Bersifat Kasuitis

Mengenai penundaan eksekusi yang bersifat Kasuitis merupakan hal yang bersifat konsepsional dari prinsip yang bersifat umum. Tentang bagaimana suatu alasan dapat dianggap bersifat kasuistik, hal ini sangat tergantung pada pendapat dan pertimbangan Ketua Pengadilan Agama. Secara umum hal-hal yang bersifat kasuistik dapat terjadi dalam halhal sebagai berikut: ${ }^{32}$

a. Alasan kemanusiaan.

b. Alasan derden verzet.

Untuk para pihak yang mempunyai hak atas obyek sengketa yang tidak dapat dieksekusi (non executable) meskipun eksekusi tersebut dalam status dihentikan tapi eksekusi tidaklah final, masih ada upaya penyelesaian yang diantaranya adalah: ${ }^{33}$

Pertama, dengan cara mengajukan gugatan, dalam hal ini diatur dalam HIR pasal 118. Para pihak yang berperkara dapat mengajukan gugatan baru ke Pengadilan dalam rangka mendapatkan haknya kembali. Menurut pendapat Yahya Harahap, para pihak yang berperkara dibenarkan mengajukan gugatan baru meskipun bersinggungan dengan asas nebis in idem yang menyatakan bahwa seseorang tidak boleh dituntut sekali lagi karena suatu peristiwa atau suatu perbuatan yang baginya telah diputus Hakim atau baginya telah diberikan status berdasarkan suatu putusan.

Hal tersebut dapat dilakukan apabila gugatan mengandung salah satu cacat formil yang dalam kasus ini gugatan dari penggugat tidak jelas batas atau luas tanah yang itu termasuk dalam gugatan obscuur libel atau cacat. Maka putusan tersebut tidak mengandung nebis in idem, tidak memiliki daya kepastian hukum, karena belum menyentuh

\footnotetext{
32 Hensyah Syahlani, Juru Sita dan Penyitaan Putusan dan Eksekusi Pada Pengadilan Agama, Mahkamah Agung RI, Jakarta, 1990, hal. 49

${ }^{33}$ Mahkamah Agung RI, Pedoman Pelaksanaan Tugas dan Administrasi Peradilan, MA RI, Jakarta, 2010, hal. 100
}

pokok perkara, tidak mengikat kedua belah pihak dan pihak yang berkepentingan berhak mengajukan perkara untuk kedua kalinya dengan cara menghilangkan cacat formil yang melekat pada gugatan semula. ${ }^{34}$

Kedua, dengan mengajukan permohonan peninjauan kembali. Upaya hukum peninjauan kembali (PK) atau request civil merupakan upaya hukum luar biasa sebagai upaya hukum terhadap putusan yang telah memperoleh kekuatan hukum tetap, bahkan putusan itu sudah dilaksanakan atau dieksekusi. Pemohonan PK terjadi apabila ada alasan untuk itu dan dirasakan tidak adil. Upaya ini terjadi apabila pihak-pihak yang berperkara keberatan dan dirugikan oleh putusan yang telah memperoleh hukum tetap.

Dalam UU No. 14 Tahun 1985 tentang Mahkamah Agung menyebutkan PK hanya dapat diajukan 1 kali. PK tidak menangguhkan atau menghentikan pelaksanaan putusan pengadilan. PK dapat dicabut selama belum diputus, dan kalau sudah dicabut maka tidak lagi diajukan PK untuk kedua kali.

\section{PENUTUP}

\section{A. Kesimpulan}

1. Cara pelaksanaan eksekusi dalam Hukum Acara Perdata adalah: Pelaksanaan putusan atas perintah dan atau dipimpin ketua pengadilan Negeri, sebelum pelaksanaan eksekusi diberikan peringatan (aanmaning). Jika tidak mengindahkan, maka dilakukan sita eksekusi. Penyitaan dilakukan oleh panitera atas perintah Ketua Pengadilan Negeri. Sita eksekusi harus disaksikan oleh dua orang saksi. Barang yang disita tetap berada pada yang disita atau ditempatkan pada penyimpanan yang layak. Penyitaan benda tidak bergerak dilakukan dengan membuat berita acara.

2. Putusan Hakim yang sudah mempunyai kekuatan hukum tetap tidak dapat dieksekusi, alasannya: Karena harta kekayaan tereksekusi tidak ada. Karena putusan bersifat deklaratoir (pernyataan). Barang yang menjadi

\footnotetext{
${ }^{34}$ Rasyid Mushar, Hakekatnya Kekuatan Nebis in idem, Diakses pada tanggal 4 Oktober 2016
} 
objek eksekusi berada ditangan pihak ketiga. Eksekusi tidak dapat dijalankan terhadap penyewa. Karena tanah yang akan dieksekusi tidak jelas batasbatasnya. Tanah berubah status menjadi tanah Negara. Barang yang menjadi objek eksekusi berada di luar Negeri. Terdapat dua putusan yang saling bertentangan.

\section{B. Saran}

1. Salah satu kendala dalam pelaksanaan eksekusi adalah biaya, terkadang pihak pemohon tidak mampu membayar biaya eksekusi yang diperlukan dalam pelaksanaan eksekusi yang dilaksanakannya. Biaya yang diperlukan meliputi biaya pendaftaran eksekusi, biaya saksi-saksi dan biaya pengamanan serta lain-lain yang dianggap perlu. Setelah biaya eksekusi tersebut dibayar oleh pihak yang menghendaki eksekusi kepada Panitera atau petugas yang ditunjuk untuk mengurus biaya perkara, barulah pemohon eksekusi tersebut didaftarkan dalam register eksekusi.

2. Masalah lain yang juga menghambat pelaksanaan eksekusi, yaitu :

a. Tereksekusi menolak karena tidak sesuai dengan bunyi putusan pengadilan.

b. Kedua belah pihak menolak eksekusi karena tidak sesuai dengan amar putusan.

c. Harta bersama kalau tidak mendapat persetujuan suami atau istri maka eksekusi tidak dapat dilaksanakan terhadap harta bersama.

d. Eksekusi tidak dapat dilaksanakan terhadap tergugat lain yang tidak banding atau kasasi.

e. Barang yang sudah selesai dieksekusi tidak dapat diambil kembali oleh pihak tereksekusi.

\section{DAFTAR PUSTAKA}

Abdul Kadir Muhammad, Hukum Acara Di Indonesia, Alumni, Bandung, 1978.

Arto A. Mukti, Praktek Perkara Perdata Pada Peradilan Agama, Rajawali, Jakarta, 1996.
Asnawi M. Natsir, Hermeneutika Putusan Hakim, UII Press, Yogyakarta, 2006.

Bachir Djazuli, Eksekusi Putusan Perkara Perdata : Segi Hukum dan Penegakan Hukum, Penerbit Akademika Pressindo, Jakarta.

Harahap M. Yahya, Ruang Lingkup Permasalahan Eksekusi Bidang Perdata, Gramedia, Jakarta, 1991.

Makarao Moh. Taufik, Pokok-Pokok Hukum Acara Perdata, Rineka Cipta, Jakarta, 2009.

Manan H. Abdul, Penerapan Hukum Acara Perdata di Lingkungan Peradilan Agama, Kencana, Jakarta, 2006.

Mertokusumo Sudikno, Hukum Acara Perdata Indonesia, Liberty, Yogyakarta, 1985.

Prodjodikoro Wirjono, Hukum Acara Perdata di Indonesia, Penerbit, Sumur, Bandung, 1984.

Rasaid M. Nur, Hukum Acara Perdata, Penerbit Sinar Grafika, Jakarta, 2008.

Saleh K. Wantijk, Hukum Acara Perdata $H I R / R B g$, Ghalia Indonesia, Jakarta, 1989.

Soekanto Soerjono dan Mamudji Sri, Penelitian Hukum Normatif, Suatu Tinjauan Singkat, RajaGrafindo Persada, Jakarta, 2004.

Spinst Darwan, Strategi Menyusun dan Menangani Gugatan Perdata, Citra Aditya Bakti, Bandung, 1992.

Sulistini Elise T. dan Erwin Rudy T., Petunjuk Praktis Menyelesaikan Perkara-Perkara Perdata, Bina Aksara, Jakarta, 1987.

Supomo R., Hukum Acara Perdata Pengadilan Negeri, Pradnya Paramita, Jakarta, 1980.

Sungono Bambang, Metodologi Penelitian Hukum, RajaGRafindo Persada, Jakarta, 2001.

Sutantio Retnowulan dan Oeripkartawinata Iskandar, Hukum Acara Perdata dalam Teori dan Praktek, Alumni, Bandung, 1986.

Syahlani Hensyah, Juru Sita dan Penyitaan Putusan dan Eksekusi Pada Pengadilan Agama, Mahkamah Agung RI, Jakarta, 1990.

Peraturan Perundang-undangan

R.bg (Rechtsreglement Buitengewestez) 
Lex et Societatis, Vol. V/No. 1/Jan-Feb/2017

HIR (Herziene Inlands Reglement)

BW (Burgerlijk Wetboek) Kitab Undang-Undang Hukum Perdata

Undang-Undang No. 4 Tahun 2004 tentang Kekuasaan Kehakiman

Undang-Undang No. 8 Tahun 2004 tentang Peradilan Umum

Undang-Undang No. 5 Tahun 2004 tentang Mahkamah Agung RI

Undang-Undang No. 3 Tahun 2006 tentang Peradilan Agama 